\title{
COVID-19 in Africa: preparing for the storm
}

J. Chakaya, ${ }^{1,2}$ A. Binegdie, ${ }^{3}$ A. Irungu, ${ }^{4}$ B. Pearson, ${ }^{5}$ D. Gray, ${ }^{6}$ H. J. Zar, ${ }^{7}$ I. Schewitz, ${ }^{8}$ J. Kagima, ${ }^{2,9}$ K. Mortimer, ${ }^{2}$ O. B. Ozoh, ${ }^{10}$ R. Masekela, ${ }^{11}$ S. B. Gordon, ${ }^{2,12}$ W. Worodria, ${ }^{13}$ J. Aluoch $^{14}$

${ }^{1}$ Department of Medicine, Dermatology, Psychiatry and Therapeutics, Kenyatta University, Nairobi, Kenya; ${ }^{2}$ Department of Clinical Sciences, Liverpool School of Tropical Medicine, Liverpool, UK; ${ }^{3}$ Division of Pulmonary and Critical Care Medicine, Department of Internal Medicine, School of Medicine, College of Health Sciences, Addis Ababa University, Addis Ababa, Ethiopia; ${ }^{4}$ Gertrude's Children's Hospital, Nairobi, Kenya; ${ }^{5}$ FSG Africa Limited, Cambridge, UK; ${ }^{6}$ Division of Paediatric Pulmonology, Department of Paediatrics and Child Health, University of Cape Town, Cape Town, South Africa; ${ }^{7}$ Department of Paediatrics \& Child Health and SA Medical Research Council Unit on Child \& Adolescent Health, Red Cross Children's Hospital, University of Cape Town, Cape Town, South Africa; ${ }^{8}$ Department of Cardiothoracic Surgery, University of Pretoria, Pretoria, South Africa; ${ }^{9}$ Department of Internal Medicine, Kenyatta National Hospital, Nairobi, Kenya; ${ }^{10}$ Department of Medicine, College of Medicine, University of Lagos, Lagos, Nigeria; ${ }^{11}$ Department of Paediatrics and Child Health, Nelson R Mandela School of Clinical Medicine, College of Health Sciences, University of KwaZulu Natal, Durban, South Africa; ${ }^{12}$ Malawi-Liverpool Wellcome Trust Clinical Research Programme, Queen Elizabeth Central Hospital, College of Medicine, Blantyre, Malawi; ${ }^{13}$ Infectious Diseases Research Collaboration, Mulago Hospital, Makerere University, Kampala, Uganda; ${ }^{14}$ The Nairobi Hospital, Nairobi, Kenya

Correspondence to: Jeremiah Chakaya, P.O Box 19692-00202, Nairobi, Kenya. e-mail: chakaya.jm@gmail.com

Running head: COVID-19 preparedness in Africa

Article submitted 24 April 2020. Final version accepted 4 May 2020. 


\section{Dear Editor,}

The world is in the midst of a major public health emergency in the form of COVID-19. The pandemic, first noted in Wuhan, China, in December 2019 has since spread to nearly all countries of the world, with more than 3 million people testing positive for the virus, which has caused more than 200,000 deaths (as of 2 May 2020). ${ }^{1}$ The full impact of the pandemic remains unclear as the situation continues to evolve.

Although the majority of infected people have mild disease, severe pneumonia and death occurs in about $7 \%$ of affected people. ${ }^{2}$ People at risk of severe disease and death include the elderly and those with comorbid disease states such as hypertension, chronic cardiac disease, chronic respiratory disease, chronic kidney disease and diabetes. ${ }^{3-5}$ However, it is worth noting that there are currently no studies from Africa, where in some settings fewer than $10 \%$ of hypoxic patients receive oxygen. ${ }^{6}$

Until now, the 46 countries that comprise the WHO African Region have experienced a low-level pandemic, with only $0.8 \%$ of all global cases and $0.4 \%$ of all deaths. ${ }^{2}$ It is not clear why Africa is reporting these low numbers, but the late introduction of the virus at the start of the pandemic ${ }^{7,8}$ and inadequate testing have been advanced as the primary reasons. Although case notifications from sub-Saharan Africa (SSA) have not conformed to modelling studies, ${ }^{9}$ there is genuine concern that this region could be the fourth epicenter of COVID-19 (after China, Europe and the United States), with the full force of the disease hitting Africa in the coming months. Others have optimistically suggested that Africa might escape the storm of COVID-19. This optimism is based on observations that countries with BCG vaccination coverage appear to have a low pandemic level (presumed to be related to non-specific immune function enhancement by BCG vaccination), ${ }^{10}$ while climate ${ }^{11}$ and the relatively young population may also play a role. While we acknowledge that these factors might influence disease progression, there is no currently no evidence for or against, and what is being observed may simply be the lull before the storm.

There are many reasons for Africa to urgently prepare for an anticipated COVID-19 storm. These include the large population that is vulnerable because of existing conditions, such as HIV-infected persons (68\% of the 37.9 million people living with HIV in the world), ${ }^{12}$ alongside the burden of chronic obstructive pulmonary disease, ${ }^{13}$ diabetes, ${ }^{14}$ and tuberculosis (TB), which may lead to more severe disease. ${ }^{15}$ The effects of poverty and social deprivation (including indoor air pollution, overcrowding, malnutrition, poor access to clean water and sub-optimal access to quality health services) may further increase the risk of exposure to 
infection and or severity of disease, in addition to constraining our ability to fully implement measures to limit transmission.

The weak health care systems in SSA is another reason for concern. Health care worker density in SSA is among the lowest in the world and is insufficient to meet the targets of the UN Sustainable Development Goals. Specialised personnel that are needed to provide care to COVID-19 patients, such as infectious disease specialists, pulmonologists, intensivists and critical care nurses, are generally scarce in SSA. The redeployment of health care workers to the COVID-19 response could also lead to weakening of primary and secondary health care, disrupt service delivery for endemic diseases and further increase population morbidity and mortality, especially among children. Furthermore, if senior, experienced physicians fall ill and die, the precious legacy of medical educators that has only recently been established will take several generations to replace.

The provision of essential protective equipment for health care workers is likely to be a major challenge in SSA where medical product procurement and supply chain management systems are weak. Furthermore, the full morbidity and mortality impact of COVID-19 may not be known due to sub-optimal health information systems, while the large socio-economic inequalities imply the poor will bear the brunt of COVID-19.

Based on the above summary, it might appear that Africa is unable to protect itself from COVID-19. However, with forethought and planning the disaster could be averted and/or substantially mitigated (Table).

First, SSA needs to adopt a collaborative approach to finding, utilising and sharing national and regional innovations, highlighting successes and failures including mechanisms for coping with the socio-economic consequences of this new disease. These efforts should be championed by regional bodies such as the African Union, East African Community, Southern Africa Development Community, Eastern, Southern and Central Africa - Health Community and Economic Community of West African States.

Second, the region should rapidly expand testing in both public and private healthcare sectors. Tests could be obtained using cost reduction measures such as pooled procurement. The region should push for the adoption of existing rapid tests such as the Xpert (Cepheid, Sunnyvale, CA, USA) test to expand SARS-COV-2 testing, without compromising testing for other diseases. The region should also actively engage in activities related to the development, adoption and implementation of rapid antibody-based testing, which have the potential to improve our understanding of the disease epidemiology and to get people to return to work earlier. 
Third, Africa should pay attention to transmission prevention using interventions that have been proven to be effective elsewhere, including social or physical distancing, hand hygiene, universal use of masks in public, restrictions on travel and gatherings, suspension of public transport and closing of schools.

Fourth, the clinical capacity to provide care to people with COVID-19 needs to be expanded rapidly through fast-tracked hiring and training of new health staff, access to oxygen at all levels of the health care system, enhancement of patient referral systems and task sharing and/or shifting. As attention shifts to the COVID-19 pandemic, it is vitally important that SSA continues to provide care for TB, HIV, malaria and emerging non-communicable diseases.

Finally, we propose that Africa should develop robust collaborative research programmes, funded by African governments and partners, to include epidemiological, health system, implementation, clinical trials, immunological and virological research.

Although, the future may appear extremely challenging, Africa can defeat COVID-19. The time to act is now.

Conflicts of interest: none declared.

\section{References}

1 Coronavirus Resource Center, Johns Hopkins Center for Systems Science and Engineering. Baltimore, MD, USA: JHU, 2020. https://coronavirus.jhu.edu/map.html

2 World Health Organization. Corona virus disease (COVID-19) situation report 103. Geneva, Switzerland: WHO, 2020. https://www.who.int/docs/defaultsource/coronaviruse/situation-reports/20200502-covid-19-sitrep-

\section{3.pdf?sfvrsn=d95e76d8_4. Accessed May 2020.}

3 Zhou F, Yu T, Du R, et al. Clinical course and risk factors for mortality of adults in patients with COVID-19 in Wuhan, China: a retrospective cohort study. Lancet 2020: 395 (10229): 1054-1062.

4 US Centers for Disease Control and Prevention COVID-19 Response Team. Severe outcomes among patients with Coronavirus disease (COVID-19), United States, February 12-March 16, 2020. MMWR Morb Mortal Wkly Rep 2020; 69(12): 343-346.

5 Wu C, Chen X, Cai Y. Risk factors associated with acute respiratory distress syndrome and death in patients with coronavirus disease 2019 pneumonia in Wuhan, China. JAMA Intern Med. Published online 13 March 2020; doi:1001/jamainternmed.2020.0994. 
6 Evans HT, Mahmood N, Fullerton DG, et al. Oxygen saturations of medical inpatients in a Malawian Hospital: cross -sectional study of oxygen supply and demand. Pneumonia 2016; 1: 3-6.

7 Thirumalaisamy P V, Meyer C G. The COVID-19 epidemic. Trop Med Int Health 2020; 25(3): 278-280.

8 Haider N, Yavlinsky A, Simons D, et al. Passengers' destination from China: low risk of novel Coronavirus (2019-nCov) transmission into Africa and South America. Epidemiol Infect 2020; 148: e41, 1-7.

9 Achoki T, Alam U, Were L, et al. COVID-19 pandemic in the African continent: forecast of cumulative cases, new infections and mortality. MedRxiv pre-print 156; doi: https://doi.org/10.1101/2020.04.09.20059154.

10 Miller A, Reandelar M J, Fascighone K, Roumenova V, Li Y, Otazu G. Correlation between universal BCG vaccination policy and reduced morbidity and mortality for COVID-19: an epidemiological study. MedRxiv 2020; doi: https://doi.org/10.1101/2020.03.24.20042937.

11 Berumen J, Schmulson M, Guerrero G, et al. Trends of SARS-COV2 infection in 67 countries: role of climatezone, temperature, humidity and curve behavior of cumulative frequency on duplication time. MedRxiv 2020 pre-print; doi: https://doi.org/10.1101/2020.04.18.20070920.

12 UNAIDS. UNAIDS data 2019. Geneva, Switzerland: UNAIDS, 2019. https://www.unaids.org/sites/default/files/media_asset/2019-UNAIDS-data_en.pdf Accessed May 2020.

13 Ahmed R, Robinson R, Mortimer K. Epidemiology of non-communicable respiratory disease in Sub-Saharan Africa, the Middle East and North Africa. Malawi Med J 2017; 29(2): 203-211.

14 Jaffar S, Gill G. The crisis of diabetes in sub-Saharan Africa. Lancet Diabetes Endocrinol 2017; 5(8): 574-575.

15 Liu Y, Bi L, Chen Y, et al. Active or latent tuberculosis increases susceptibility to COVID19 and disease severity. doi: https://doi.org/10.1101/2020.03.10.20033795. 
Table COVID-19 in SSA: key challenges/constraints and mitigation measures

\begin{tabular}{|c|c|c|}
\hline Constraint/challenge & Mitigation measures & Responsible agencies \\
\hline Large at-risk populations & $\begin{array}{l}\text { Population awareness, targeted } \\
\text { interventions, epidemiological } \\
\text { studies to confirm vulnerability }\end{array}$ & $\begin{array}{l}\text { National Governments/Ministries of } \\
\text { Health, local and international } \\
\text { partners }\end{array}$ \\
\hline $\begin{array}{l}\text { Inadequate human resource } \\
\text { for health }\end{array}$ & $\begin{array}{l}\text { Rapid recruitment and deployment, } \\
\text { innovative training and support, } \\
\text { task shifting and sharing, } \\
\text { telemedicine. }\end{array}$ & $\begin{array}{l}\text { National Governments/Ministries of } \\
\text { Health, local and international } \\
\text { partners }\end{array}$ \\
\hline $\begin{array}{l}\text { Weak health products } \\
\text { procurement and supply } \\
\text { chain management systems }\end{array}$ & $\begin{array}{l}\text { Temporary outsourcing of services as } \\
\text { national systems are strengthened }\end{array}$ & $\begin{array}{l}\text { National Governments/Ministries of } \\
\text { Health, local and international } \\
\text { partners }\end{array}$ \\
\hline $\begin{array}{l}\text { Inadequate critical care } \\
\text { capacity }\end{array}$ & $\begin{array}{l}\text { Decentralisation of care with emphasis } \\
\text { on oxygen provision at all levels of } \\
\text { the health care system, proning, } \\
\text { clinical guidance with in-built } \\
\text { flexibility and } \\
\text { operations/implementation research }\end{array}$ & $\begin{array}{l}\text { National Governments/Ministries of } \\
\text { Health, local and international } \\
\text { partners, research institutions }\end{array}$ \\
\hline $\begin{array}{l}\text { Weak health management } \\
\text { information systems }\end{array}$ & $\begin{array}{l}\text { Rapid adoption of electronic/digital } \\
\text { reporting platforms }\end{array}$ & $\begin{array}{l}\text { National Governments/Ministries of } \\
\text { Health, local and international } \\
\text { partners, research institutions }\end{array}$ \\
\hline $\begin{array}{l}\text { Disruption of service delivery } \\
\text { for common endemic } \\
\text { health problems (HIV, TB, } \\
\text { malaria, respiratory tract } \\
\text { infections in children) }\end{array}$ & $\begin{array}{l}\text { Policy formulation and dissemination, } \\
\text { health care worker support, } \\
\text { strengthened infection prevention } \\
\text { and control, provision of } \\
\text { appropriate protective equipment }\end{array}$ & $\begin{array}{l}\text { National Governments/Ministries of } \\
\text { Health, local and international } \\
\text { partners, research institutions }\end{array}$ \\
\hline $\begin{array}{l}\text { Managing the economic } \\
\text { consequences of } \\
\text { lockdowns }\end{array}$ & $\begin{array}{l}\text { Debt relief, provision highly } \\
\text { concessional loans, providing } \\
\text { safety nets for the poor and } \\
\text { vulnerable }\end{array}$ & $\begin{array}{l}\text { National Governments, regional and } \\
\text { international lending institutions, } \\
\text { development partners }\end{array}$ \\
\hline
\end{tabular}

SSA = sub-Saharan Africa; $\mathrm{TB}=$ tuberculosis; HIV = human immunodeficiency virus. 